\title{
Diseño de letras en carteles y cabeceras del imaginario Disney
}

\section{Design of Letters in Posters and Main Titles of Disney Imaginary \\ Design de letras em pôsteres e títulos principais do imaginário da Disney}

\author{
Dr. Ricard Huerta \\ Profesor \\ (Universitat de València) \\ https://orcid.org/0000-0002-1430-3198 \\ España \\ Dr. Vicente Monleón Oliva \\ Doctorado \\ Investigador colaborador \\ (Grupo CREARI) \\ https://orcid.org/0000-0001-8357-1316 \\ España
}

Fecha de recepción: 19 de abril de 2020

Fecha de revisión: 25 de abril de 2020

Fecha de aceptación: 15 de junio de 2020

Fecha de publicación: 1 de julio de 2020

Para citar este artículo: Huerta, R. y Monleón Oliva, V. (2020). Diseño de letras en carteles y cabeceras del imaginario Disney, Icono 14, 18 (2), 406-434. doi: 10.7195/ri14. v18i2.1574 


\section{Resumen}

En el presente artículo analizamos los diseños de letras del imaginario Disney desde la cultura visual. Indagamos en los estilos que han marcado algunas de las producciones más emblemáticas de esta productora de cine, para lo cual se seleccionan como muestra 12 filmes representativos de los 60 títulos que componen la colección Clásicos Disney. Abordamos la cuestión desde una revisión estilística, estudiando las características formales y observando el papel de cada diseño en su coyuntura histórica, mediante un estudio de caso, analizando de qué modo comunicación y tecnología se dan la mano en esta evolución estilística. También aportamos una componente educativa, atendiendo a nuestra implicación en la formación de docentes, ofreciendo un examen detallado de los carteles y los títulos de crédito. Consideramos que este material puede resultar de utilidad para comprender mejor en influjo de la sensibilidad Disney en las sucesivas generaciones de públicos. El poder de Disney en los medios afecta directamente a nuestra recepción de la literatura clásica, algo que se mantiene en cada momento, ya que Disney ha demostrado durante un siglo su capacidad de adaptación a los usos tecnológicos y las corrientes estéticas. Las letras de la iconosfera Disney nos ofrecen un catálogo exclusivo de adaptación a las modas desde la constante innovación en sus propuestas ideológicas, estéticas, tecnológicas, comunicativas y culturales.

Palabras clave: Cine; Diseño; Alfabeto; Carteles; Cultura Visual; Disney

\section{Abstract}

In this article, we analyze letters designs of Disney imaginary from visual culture. We investigate the styles that have supposed some of the most emblematic productions of this film producer, as a consequence as sample they are chosen 12 representative films of the 60 titles of Disney Classics set. Using a case study we developed a comparative to find out visual messages made with letters have clearly penetrated collective imagination. Communication and technology go together in this stylistic evolution. We also provide an educational perspective on the subject, attending to our involvement in training teacher, offering a detailed examination of posters and credits. We believe that this material can be useful to better understand the influence of Disney sensibility on successive generations of audiences. Disney's power 
in the media directly affects our reception of classical literature, something that is maintained in every process or change that happens, since Disney has demonstrated for a century its ability to adapt to technological uses and currents aesthetic. The letters of the Disney iconography offer us an exclusive catalog of adaptation to fashions from constant innovation in its ideological, aesthetic, technological, communicative and cultural proposals.

Key Words: Cinema; Design; Alphabet; Posters; Visual Cuture; Disney

\section{Resumo}

Neste artigo, analisamos os desenhos tipográficos do imaginário da Disney a partir da perspectiva da cultura visual. Investigamos os estilos que marcaram algumas das produções mais emblemáticas deste produtor de filmes, para as quais selecionamos 12 dos 60 títulos que compõem a coleção Disney Classics. Abordamos a questão estudando características formais e analisando o papel de cada projeto em sua conjuntura histórica. Desenvolvemos um comparativo que nos permite descobrir até que ponto essas mensagens visuais feitas com letras penetraram claramente na imaginação coletiva. Comunicação e tecnologia andam de mãos dadas nesta evolução estilística. Também fornecemos uma perspectiva educacional sobre o assunto, atendendo ao nosso envolvimento na formação de professores, oferecendo um exame detalhado de pôsteres e créditos. Acreditamos que este material pode ser útil para entender melhor a influência da sensibilidade da Disney nas gerações sucessivas de audiências. 0 poder da Disney na mídia afeta diretamente nossa recepção da literatura clássica, algo que é mantido em todos os processos ou mudanças que acontecem, uma vez que a Disney demonstrou por um século sua capacidade de se adaptar aos usos e correntes tecnológicas estético. As cartas da iconografia da Disney nos oferecem um catálogo exclusivo de adaptação às modas da inovação constante em suas propostas ideológicas, estéticas, tecnológicas, comunicativas e culturais.

Palavras chave: Filmes; Projeto; Alfabeto; Cartazes; Cultura visual; Disney 
INNOVACIÓN TEÓRICA

\section{Introducción}

Entendemos por cultura visual toda aquella información transmitida por medio de imágenes fijas o en movimiento que confeccionan un imaginario colectivo común (Duncum, 2015; Hernández, 2010). Disney como productora de audiovisuales de animación se relaciona con el concepto de cultura visual desde su vertiente productiva y de difusión, alcanzando niveles de carácter global, que han permitido educar a sucesivas generaciones (Lobovikov-Katz, 2019). A través de sus creaciones, Disney difunde en la ciudadanía una serie de valores vinculados a una ideología concreta, desde una mentalidad muy vinculada al esquema ideológico conservador, que opera a través de un conjunto de convenciones religiosas y políticas, que parten de los principios sociales del heteropatriarcado característico de la población norteamericana de inicios del s. XX (Cantillo, 2011 y 2015). Esta simbología Disney se transmite entre quienes consumieron sus largometrajes a lo largo de un siglo, perdurando por tanto mensajes que dificultan el progreso hacia el conocimiento y respeto de la alteridad (Barber, 2015). También en el ámbito escolar Disney ha sabido ejercer su influencia (Dewey, 2008), algo que se perpetúa en ciertos esquemas de formación universitaria (Castro-Martinez y Diaz-Morilla, 2019). Las repercusiones del impresionante efecto del imaginario Disney en la formación de varias generaciones constituyen al mismo tiempo un fuerte engranaje de calado social y comunicativo (Foucault, 1998), un magma cultural que integra a personas de todas las edades y de todo el espectro social (Briggs y Burke, 2002). Han sido muchas las voces críticas que han analizado el poder comunicativo de Disney como un verdadero estigma reaccionario (Giroux, 2001). En última instancia se trata de un imperio consolidado que confirma cómo el control de los principales conglomerados de comunicación continúa en manos de un reducido grupo de países occidentales, de modo que sus mensajes siguen contribuyendo a difundir modelos económicos, políticos y culturales hegemónicos (Vaquerizo Domínguez, 2020). Debemos ser capaces de utilizar dicho imaginario para reconsiderar su vigencia desde la práctica artística docente (Irwin y 0’Donoghue, 2012), reflexionando sobre cuestiones educativas y patrimoniales. 
A partir de la influencia que ejerce esta contundente realidad comunicativa que es Disney, nos adentramos en la evolución de los elementos compositivos en algunas de sus producciones carismáticas (Frutiger, 2007). Optamos por centrarnos en las cualidades y repercusiones que han tenido las letras en los carteles y los títulos de crédito de sus películas. Al hablar de letras y alfabetos detectamos elementos propios de las tipografías y también de las caligrafías de creación, diseños que en última instancia nos permiten identificar los cásicos Disney, que fueron creados para perdurar. Y de hecho así ha sido. Décadas después de su realización y primera difusión, las letras utilizadas en las producciones de esta marca siguen funcionando a la perfección entre públicos de todas las edades (Groupe $\mu$, 1992). Las conocemos y las reconocemos, algo que ocurre igualmente con logos como el de "Coca-Cola" o el de la propia productora Disney, que se basa precisamente en la firma del creador de este imperio (Freitas, Coutinho y Waetcher, 2013). La caligrafía de la firma de Walt Disney ha quedado impregnada en nuestra mente como un sello particular (Nake y Grabowski, 2017). Estos rasgos decididos de las mayúsculas del logo definen al mismo tiempo el vigor con el que la productora ha evolucionado adaptándose a cada momento, siempre incorporando nuevos posicionamientos tecnológicos y comunicativos.

\section{Objetivos de la investigación}

Nuestra intención es detectar aquellos aspectos formales y de contenido que identifican el imaginario Disney, desde los planteamientos de la cultura visual. Para ello nos centramos en los diseños de carteles y títulos de crédito, observando con detenimiento las letras utilizadas (Barthes, 1986). Observar y analizar estos trabajos de modo diacrónico nos permite evaluar su capacidad de adaptación, ya que la productora ha generado una mitología visual muy poderosa a lo largo de un siglo (Debord, 1967). Y a partir de aquí sondeamos las posibilidades educativas del estudio, valorando incorporar estas cuestiones en la formación del profesorado (Sancho-Gil y Hernández, 2018). ¿Qué intenta contar Disney con los tipos de letra que utiliza en los carteles de sus películas y en los títulos de crédito?; ¿cómo influye una industria cultural del imaginario colectivo en quienes consumen sus productos audiovisuales a través del diseño de letras que emplea?; ¿de qué manera se incrustan las letras Disney en la 


\section{INNOVACIÓN TEÓRICA}

memoria de la población? (Postman, 2001). Estas son las cuestiones que sirven como base y planteamiento de la investigación que se efectúa. El discurso elaborado por esta multinacional enlaza periodos, públicos y medios de comunicación (Even-Zohar, 1990). Así pues, el objetivo principal consistiría en detectar la importancia de las letras (tanto si se trata de tipografías, de caligrafías o de alfabetos de creación) en el imaginario Disney. A partir de aquí destacaríamos como intereses secundarios analizar las cualidades de algunas de dichas imágenes, profundizando tanto en su aspecto formal como en su simbología (Mirzoeff, 2006). También incorporamos la posibilidad de convertir estos hallazgos en un material válido para educar en sensibilidad (Said-Valbuena, 2019), para formar al profesorado y a públicos amplios (Freire, 2015), generando estructuras de saberes compartidos (Munari, 2019) que mejoren la educación en valores y la formación de la ciudadanía (Pacheco, Moura, Soares y Almeida, 2019), interpelando a los medios de comunicación como escaparate ideológico y cultural (McLuhan, 1994).

\section{Material y metodología}

Para el presente estudio se toma como referente la colección cinematográfica "Los clásicos Disney", un conjunto de 60 largometrajes de animación producidos entre 1937 y 2016. Estas películas se caracterizan porque en su mayoría parten de cuentos clásicos. De este conjunto, se selecciona para el análisis un total de 12, relacionadas con 12 variables que caracterizan a la productora. Asimismo, estos ejemplos son representativos de todas las décadas en las que se distribuye la colección. Se elige un filme por década a excepción de ejemplos para los años ‘ 80 , ‘90 y 2000 respectivamente, debido a la gran cantidad de producciones comercializadas en dicho momento. En consecuencia, se asume la representatividad de esta muestra de entre la pluralidad de opciones del universo Disney. Cada película sirve como ejemplo de variables constantes en las tendencias cinematográficas de la productora. 
Diseño de letras en carteles y cabeceras del imaginario Disney | 412

INNOVACIÓN TEÓRICA

\begin{tabular}{|c|c|c|c|c|c|c|}
\hline Película & Año & Productores & Directores & Productora & Variable & Lugar \\
\hline Fantasía & 1940 & Disney, W. & $\begin{array}{l}\text { Algar, J., Armstrong, S., Beebe, } \\
\text { F., Ferguson, N., Handley, J., } \\
\text { Hee, T., Jackson, W., Kuske, H. } \\
\text { y Roberts, B. }\end{array}$ & $\begin{array}{l}\text { Walt Disney } \\
\text { Pictures y RKO } \\
\text { Pictures }\end{array}$ & Cortometrajes & \\
\hline Música, maestro & 1946 & Disney, W. & $\begin{array}{l}\text { Clark, L., Geronimi, C., Larson, } \\
\text { E. y Reitherman, W. }\end{array}$ & Walt Disney & Película musical & \\
\hline $\begin{array}{ll}\text { La bella } \\
\text { durmiente }\end{array}$ & 1959 & Disney, W. & $\begin{array}{l}\text { Clark, L., Geronimi, C., Larson, } \\
\text { E. y Reitherman, W. }\end{array}$ & $\begin{array}{l}\text { Walt Disney } \\
\text { Animarion } \\
\text { Studios }\end{array}$ & $\begin{array}{l}\text { Princesa de la } 1^{a} \\
\text { era }\end{array}$ & \\
\hline Los Aristogatos & 1970 & $\begin{array}{l}\text { Hibler, W. y } \\
\text { Reitherman, } \\
\text { w. }\end{array}$ & Reitherman, W. & $\begin{array}{l}\text { Walt Disney } \\
\text { Pictures }\end{array}$ & $\begin{array}{ll}\text { Sin referente } \\
\text { literario }\end{array}$ & EE.UU. \\
\hline La bruja novata & 1971 & Walsh, B. & Stevenson, $R$. & $\begin{array}{l}\text { The Walt Disney } \\
\text { Company }\end{array}$ & Realidad-ficción & \\
\hline $\begin{array}{l}\text { Taron y el caldero } \\
\text { mágico }\end{array}$ & 1985 & Hale, J. & Berman, T. y Rich, R. & $\begin{array}{l}\text { Walt Disney } \\
\text { Pictures }\end{array}$ & $\begin{array}{ll}\text { Con referente } \\
\text { literario }\end{array}$ & \\
\hline $\begin{array}{l}\text { Los rescatadores } \\
\text { en Canguro- } \\
\text { landia }\end{array}$ & 1990 & $\begin{array}{l}\text { Schumacher, } \\
\text { T. }\end{array}$ & Butoy, H. y Gabriel, M. & $\begin{array}{l}\text { Walt Disney } \\
\text { Pictures }\end{array}$ & Animales & \\
\hline Pocahontas & 1995 & Pentecost, J. & Gabriel, M. y Golsdberg, M. & $\begin{array}{l}\text { Walt Disney } \\
\text { Pictures }\end{array}$ & Mujer no princesa & \\
\hline Mulan & 1998 & Coats, $P$. & Cook, B. y Bancroft, T. & $\begin{array}{l}\text { Walt Disney } \\
\text { Pictures y Walt } \\
\text { Disney Feature } \\
\text { Animation }\end{array}$ & LGTBIQ & \\
\hline $\begin{array}{l}\text { El planeta del } \\
\text { Tesoro }\end{array}$ & 2002 & $\begin{array}{l}\text { Clements, R., } \\
\text { Conli, R. y } \\
\text { Musker, J. }\end{array}$ & Clements, R. y Musker, J. & $\begin{array}{l}\text { Walt Disney } \\
\text { Pictures y Walt } \\
\text { Disney Feature } \\
\text { Animation }\end{array}$ & Película futurista & \\
\hline Tiana y el sapo & 2009 & $\begin{array}{l}\text { Del Vecho, P. } \\
\text { y Lasseter, J. }\end{array}$ & Clements, R. y Musker, J. & $\begin{array}{l}\text { Walt Disney } \\
\text { Pictures }\end{array}$ & $\begin{array}{l}\text { Princesa de la } 2^{\circ} \\
\text { era }\end{array}$ & \\
\hline $\begin{array}{l}\text { Forzen: el reino } \\
\text { de hielo }\end{array}$ & 2013 & $\begin{array}{l}\text { Del Vecho, P. } \\
\text { y Lasseter, J. }\end{array}$ & Buck, C. y Lee, J. & $\begin{array}{l}\text { Walt Disney } \\
\text { Animarion } \\
\text { Studios y Walt } \\
\text { Disney Pictures }\end{array}$ & $\begin{array}{l}\text { Princesa de la } 3^{a} \\
\text { era }\end{array}$ & \\
\hline
\end{tabular}

Figura 1: Materiales utilizados categorizados por décadas y variables

DOI: ri14.v18i2.1574 || ISSN: 1697-8293 | Julio - diciembre 2020 Volumen 18 № 2 | ICONO14 


\section{INNOVACIÓN TEÓRICA}

De la década de 1930 se selecciona el largometraje Fantasía, primer título de la colección, que se produce a partir de cortometrajes. De los años 1940 elegimos Música, maestro, un filme caracterizado por el uso de la música como lenguaje transmisor de ideas y como medio de comunicación. Para representar la década de 1950 recurrimos a La bella durmiente, con la última princesa enmarcada en la primera era ( $2^{\mathrm{a}}$ ola feminista). La seleccionamos porque mantiene las mismas características de sumisión que la primera de la colección.

Contextualizado en la década de 1960, Los Aristogatos es un largometraje sin origen literario, que resulta significativo debido a que dista notoriamente del resto de películas de la colección, sin un referente en la literatura, como ocurre en los filmes musicales, futuristas o aquellos que combinan realidad y ficción. De la década de 1970 se toma La bruja novata, un clásico honorífico debido a que su producción está basada en la combinación de la realidad con la animación. Es el único ejemplo de la colección que introduce el conflicto bélico (II Guerra Mundial).

Para representar la década de 1980 hemos elegido Taron y el caldero mágico, un largometraje con origen literario que dista en cuanto a temática, ya que recurre al género de la leyenda y la fantasía, y Los rescatadores en Cangurolandia, una película de animales que actúa como secuela de Los rescatadores. Los dos productos audiovisuales seleccionados de la década de 1990 son Pocahontas y Mulan. La primera es un filme cuya protagonista no pertenece a la realeza, lo cual resulta significativo para la muestra, ya que es el primer producto Disney en el que la alteridad se contempla como víctima, y a la sociedad occidental como agresora. La segunda podríamos plantearla como ejemplo de animación con vertiente LGTBIQ, ya que incorpora personajes con género diverso.

Representando a la primera década del s. XXI seleccionamos El planeta del tesoro, largometraje que dentro de la colección contempla una realidad futura. De la misma década elegimos Tiana y el sapo como película de princesas de la segunda era ( $3^{\text {a }}$ ola feminista) que presenta la única protagonista de raza negra de la colección. Cerramos la selección con Frozen: el reino de hielo, contextualizado en la década 2010, que representa la variable de las princesas de la $3^{\text {a }}$ 
era (cuarta ola feminista) ofreciendo visibilidad a la mujer sexualmente diversa a través de Elsa.

Tras seleccionar las doce películas, procedemos a un esquema de estudio de caso de las letras utilizadas (Stake, 2005). Se analizan los carteles (en inglés y español) con los que se publicitaron dichos largometrajes, valorando las diferencias y similitudes entre ambos. Asimismo se estudian semejanzas y disonancias en comparación con las carátulas de dichas películas, y entre la versión inglesa y la española. Cerramos la investigación con un acercamiento a los main title y end title de cada film. Todo ello se desarrolla en base al análisis de figuras fijas y en movimiento propias de la cultura visual, por lo que recurrimos también a la Investigación Basada en Imágenes (Alonso-Sanz, 2013) como ejemplo de investigación de corte artístico (Aguirre, 2005; Hernández, 2008), que se configura en base a la denominada Art Based Research ABR (Rolling, 2017).

\section{Cultura visual Disney}

La evolución de las estéticas visuales que han definido las producciones Disney viene marcada por la constante adecuación a las técnicas que definen cada momento histórico. En la exposición Disney, el arte de contar historias, producida por CaixaForum, pudimos comprobar, mediante originales, el desarrollo de las representaciones, apreciando cada material y proceso utilizado, desde el lápiz sobre papel en los primeros dibujos realizados por el propio Walt Elias Disney (1901-1966), hasta las técnicas de diseño por ordenador más recientes de las últimas producciones. Interesado desde muy joven por el dibujo, fue enviado a Europa durante la Primera Guerra Mundial en la unidad de ambulancias de la Cruz Roja. Al regresar a Kansas realiza viñetas publicitarias. En los años '20 se instala en Hollywood y funda un estudio junto a su hermano Roy. En 1928 estrenó El barco de vapor Willie, los primeros dibujos animados en los que se sincronizan totalmente imagen y sonido. En 1932 incorpora el color a la animación con el corto Flores y árboles, y en 1937 estrena El viejo molino, su primer corto rodado con la técnica de cámara multiplano. El mismo año estrenó Blancanieves y los siete enanitos, primer largometraje animado de la historia. Desde entonces, la adaptación de esta multinacional del entretenimiento a los sucesivos cambios y 
progresos tecnológicos, ha supuesto un contacto permanente con las tecnologías de la imagen punteras en cada momento.

Ha existido un constante flujo de interacciones entre las estéticas promovidas por la multinacional Disney y las producciones de muchas culturas locales que han adecuado los gustos del público a las modas que se iban sucediendo (Albaladejo Ortega y Sánchez Martínez, 2019). La hibridación que promueven el cómic, la publicidad y la cultura popular provoca creaciones estéticas semejantes. Entre estas hibridaciones podríamos destacar la estética de la cerámica "Lladró", una marca internacional de porcelana decorativa, que triunfó en las décadas de 1960 a 1990 elaborando un producto que nos recuerda el estilo un tanto kitsch y relamido de Disney (Ramon, 2012). Algo similar ocurre con una determinada estética de las Fallas de Valencia, monumentos efímeros que han optado por un estilo hegemónico que podríamos considerar cursi, pero que son un referente histórico. En ambos casos destaca la capacidad de Disney para penetrar en los hábitos cotidianos de la ciudadanía de prácticamente todo el planeta, mediante una estética muy aceptada por el público mayoritario, que la adapta a sus rutinas de proximidad desde perspectivas peculiares (Ramon, 2017). Así pues, no estamos hablando de una moda pasajera, sino de un estado permanente de influencia visual, que repercute en un ambiente cotidiano de control, instaurado desde la total aceptación (Benjamin, 2003).

\section{Las letras en los carteles Disney}

En el cartel de Fantasía hallamos un juego de paralelismos entre la tipología utilizada para su versión en inglés, y la que Cifesa difundió en España en un primer momento. Es interesante este título, puesto que no cambia al traducirlo, conservando en la versión doblada al español su original "Fantasía". El problema de las traducciones al español, en las producciones norteamericanas, es que en numerosas ocasiones suele cambiar, transformando incluso el sentido original. Este proceso perjudica también al estilo gráfico de las letras, cuando a pesar de conservar la palabra, se "traduce" la forma del grafismo. En el caso que analizamos, vemos que la distribuidora Cifesa optó por utilizar la versión en mayúsculas, calcando prácticamente el cartel original, donde también vemos 
destacado el eslogan "el triunfo del color y de la música con la Orquesta Filarmónica de Filadelfia bajo la dirección del maestro Stokowski". Domina el diseño tipográfico, es decir, el tipo de letras que sigue la tradición de la imprenta y la composición con tipos móviles. Se alternan las mayúsculas y las minúsculas, con diferencias notables en cuanto a colores y registros compositivos utilizados.
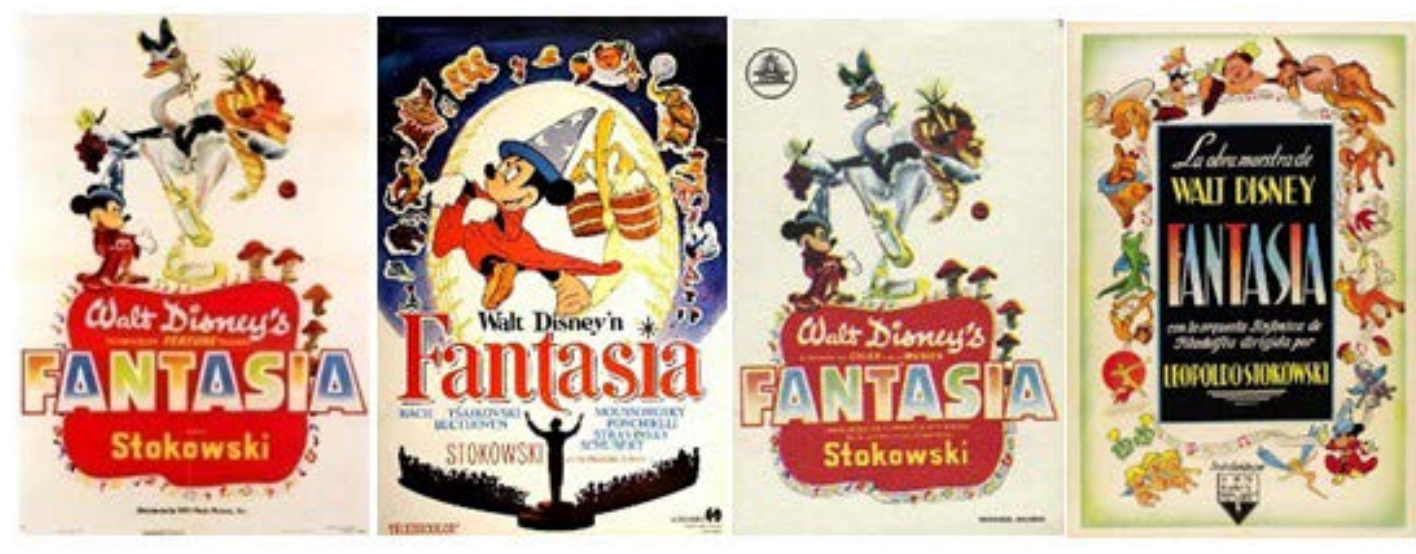

Figura 2: Carteles del film Fantasía (Fantasia, Disney, 1940)

La película ha tenido varias reposiciones, y en cada una de ellas ha cambiado el estilo de las letras, pasando incluso a convertir en minúsculas con serifa lo que inicialmente habían sido mayúsculas de palo. Al tener solamente una palabra como título, en la composición del cartel aparece centrada y muy destacada, pudiendo adoptar el estilo gráfico de cada momento en que fue distribuida. Del mismo modo que en las reposiciones del film vemos nuevos modelos tipográficos en el cartel, también la película original es sometida a una severa transformación técnica, adaptándose a cada nueva innovación tecnológica. Un caso evidente de esta transformación es el momento en que, con la introducción del DVD y las copias digitales a finales del siglo XX, se recupera Fantasía, incorporando una tipografía que vuelve a las mayúsculas originales, pero mucho más estilizadas. 

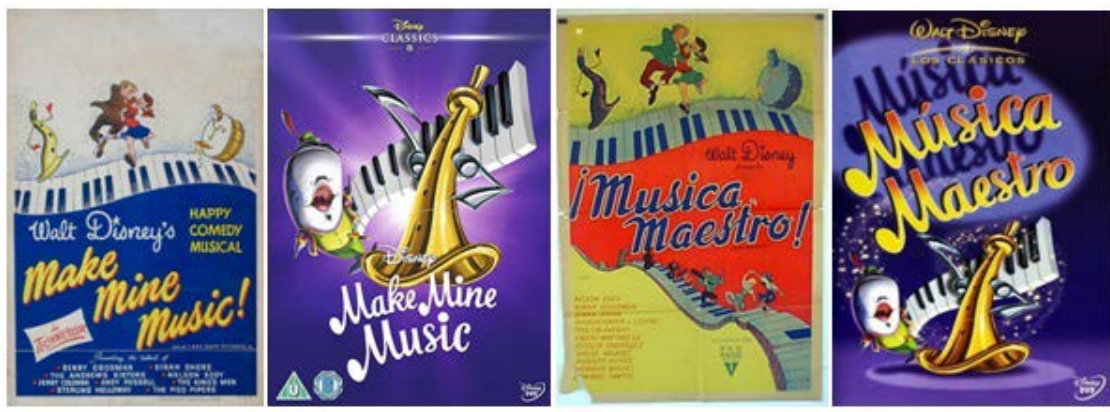

Figura 3: Carteles de Música maestro (Make Mine Music!, Disney, 1946)

En el cartel original en inglés de Make Mine Music! vemos dos figuras infantiles bailando sobre un teclado de piano, dos personajes rodeados por instrumentos de viento y percusión. De nuevo la música es el reclamo, implicando a grandes intérpretes, orquestas y directores. Doblado como ¡Música maestro!, en el cartel de la distribuidora RKO se mantiene el mismo esquema, pero transmuta a color rojo la zona central, que en la versión inglesa es azul intenso. Cambia la tipografía, imitando la original, manteniendo la caja alta y baja, simulando una caligrafía propia de la escritura escolar del momento. Cuando se recupera para difundir en DVD, tanto la versión en inglés como su traducción al español mantienen un mismo esquema de color, composición, esquema y tipografía. Las letras imitan la grafía musical, y se conservan los instrumentos que bailaban sobre el teclado, incorporando una ballena vestida de príncipe tirolés (en referencia al personaje principal del último cortometraje del film El ballenato que quiso cantar ópera). El curioso "clarinete" (parece una chirimía) que baila constituye un metafórico homenaje a Benny Goodman, auténtica figura de la banda sonora.
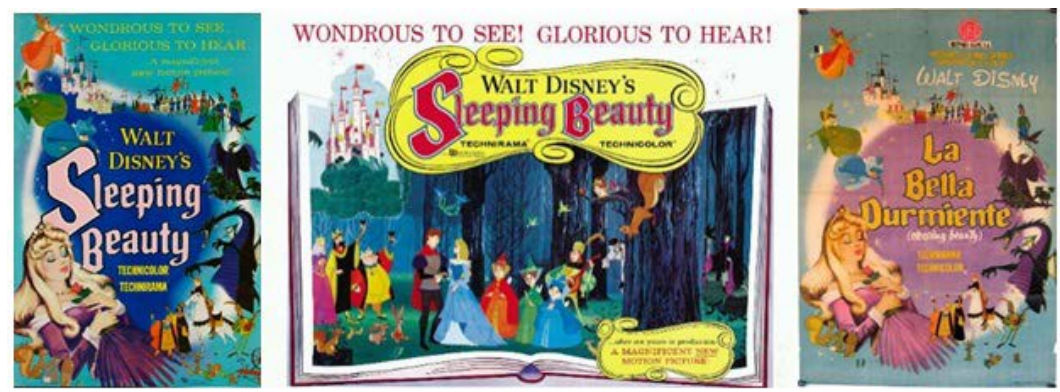

Figura 4: Carteles de la producción La bella durmiente (Sleeping Beauty, Disney, 1959) 
En el caso de La bella durmiente hallamos una cuestión que se convertirá en recurrente en otras películas, ya que la Edad Media es fuente de inspiración para numerosos clásicos de la literatura infantil. Cuando son adaptados por Disney, el tipo de letras que se utiliza se acerca a las caligrafías de los manuscritos medievales, donde podemos encontrar referencias a la uncial redonda, la minúscula carolingia, la gótica o la minúscula humanista. En las letras del cartel de Sleeping Beauty encontramos una versión híbrida de todas ellas, si bien predomina una interpretación libre de la letra gótica. El juego de colores nos lleva irremediablemente al rosa, en complicidad con las supuestas preferencias asignadas a las niñas desde el imaginario del patriarcado.
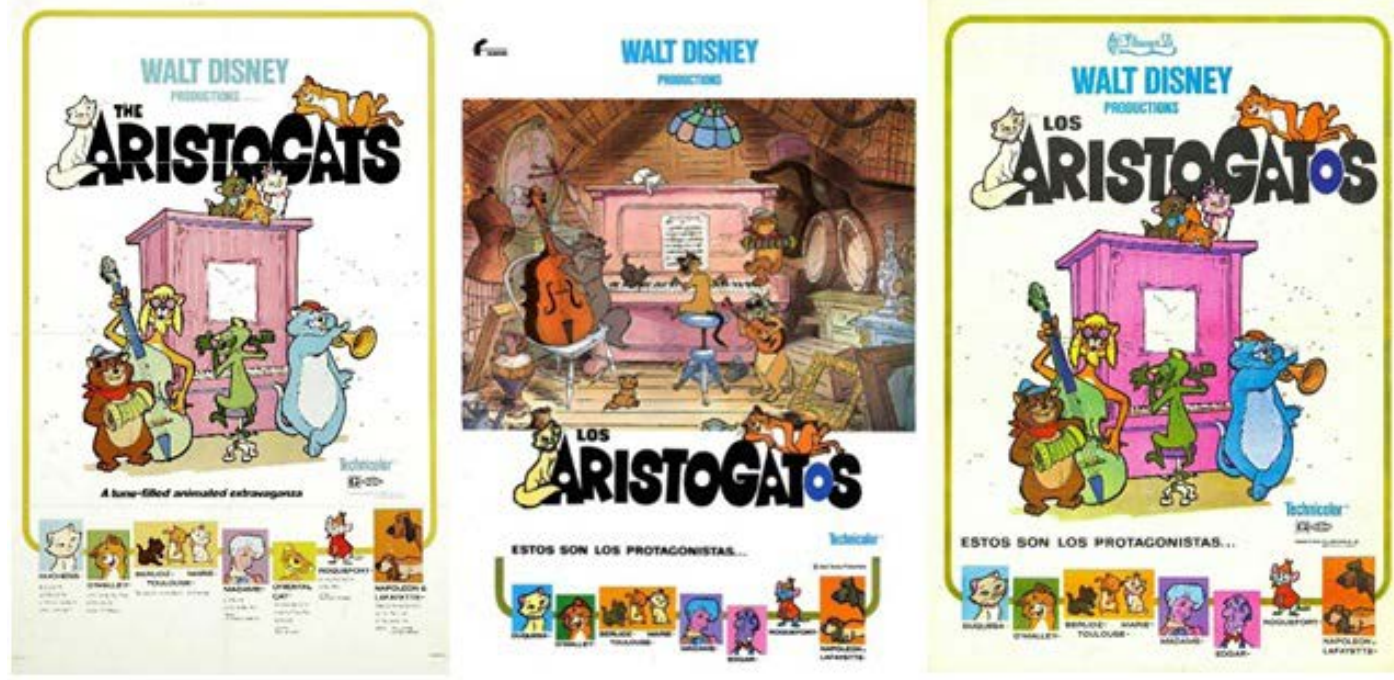

Figura 5: Carteles de la película Los Aristogatos (The Aristocats, Hibler y Reitherman, 1970)

El cartel de Los Aristogatos nos traslada a una época de efervescencias op art y pop art. Unas mayúsculas negras geométricas con un juego elaborado entre círculos y ángulos sobresalen de un fondo blanco en el que pululan diversos personajes del film. Se trata de un musical, un homenaje al jazz, con el trasfondo de una historia de amor entre felinos. De nuevo el piano (en este caso vertical, de color rosa) y varios instrumentos de cuerda, viento y percusión, acompañan al elenco gatuno. Al ser el 
INNOVACIÓN TEÓRICA

título tan similar, vemos que solamente cambia la letra $\mathrm{G}$ (una $\mathrm{C}$ en el original inglés), que ha resultado muy fácil de acoplar al conjunto de letras de creación del título. Puede que sea uno de los mejores carteles de los que estamos comentando, muy acorde con un momento histórico con el que finalizaba una década llena de sublevaciones y luchas de todo tipo, destacando el Mayo francés de 1968.
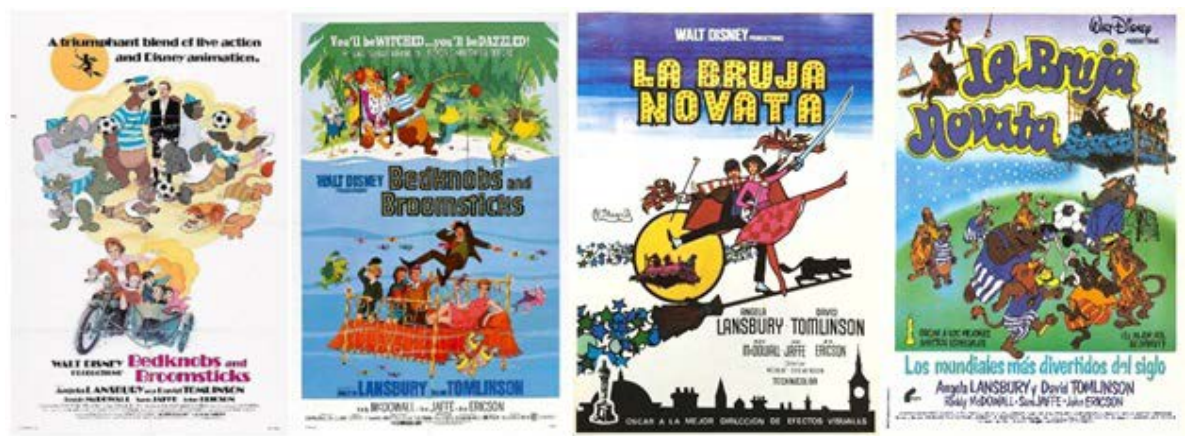

Figura 6: Carteles de La bruja novata (Bedknobs and Broomsticks, Walsh, 1971)

La versión original en inglés del cartel de La bruja novata nos presenta un esquema muy característico del revival que hubo en 1970 de letras déco y películas ambientadas los llamados "felices años '20". El fondo blanco da paso a unas letras en negro y otras en rosa con tipografía de palo seco de fantasía (Broadway), combinando mayúsculas y minúsculas. Caracteres marcadamente geométricos que facilitan su lectura y dejan un fondo completamente despejado. En la otra versión en inglés del cartel prima el fondo azul y las letras pasan a ser de anuncio luminoso, negras con puntos amarillos en el interior, a modo de bombillas. La estética es completamente distinta al anterior. Unas letras similares encontramos en la versión de la distribuidora Filmayer, aunque en este caso son amarillas, mayúsculas, rematadas con grafismo negro y con unos puntos naranja en su interior. El dibujo que acompaña a estas letras se enmarca en un tipo de ilustración popular muy habitual entre los años ' 60 y '70. El otro ejemplo también de Filmayer, aunque algo posterior (reposición del film, en época de mundiales de fútbol: “los mundiales más divertidos del siglo"), incorpora unas letras de creación, con caja alta y baja, en azul con márgenes amarillos, similares a las letras con las que dibujábamos los títulos de los trabajos escolares. 

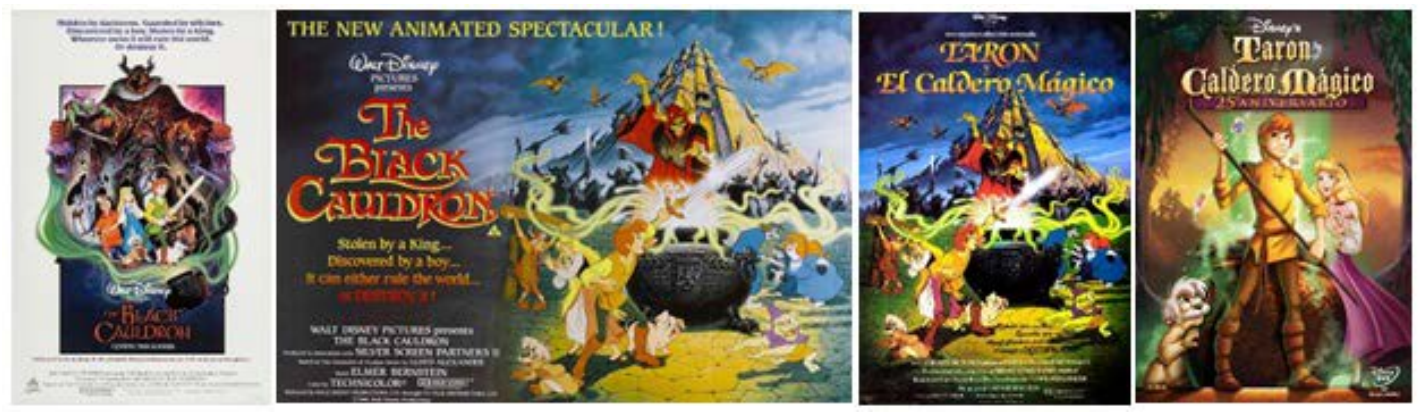

Figura 7: Carteles de Taron y el caldero mágico (The Black Cauldron, Hale, 1985)

En Taron y el caldero mágico volvemos a encontrar referencias medievales, algo que se refleja en las letras del título. Pero la gran variedad de opciones que nos presentan tanto la versión en inglés como en español vuelven a redundar en creaciones peculiares ambientadas en mayúsculas con reminiscencias celtas, especialmente interesantes por la B de Black en el cartel original, pero que se convierten en fuentes poco atractivas e incluso insípidas al pasar a la versión española, tanto en el cartel original, como en la cubierta del DVD con el que se repuso el film a los 25 años de su estreno. En un caso así detectamos una cierta cercanía a la estética que predomina en las portadas de libros infantiles con grandes tiradas.
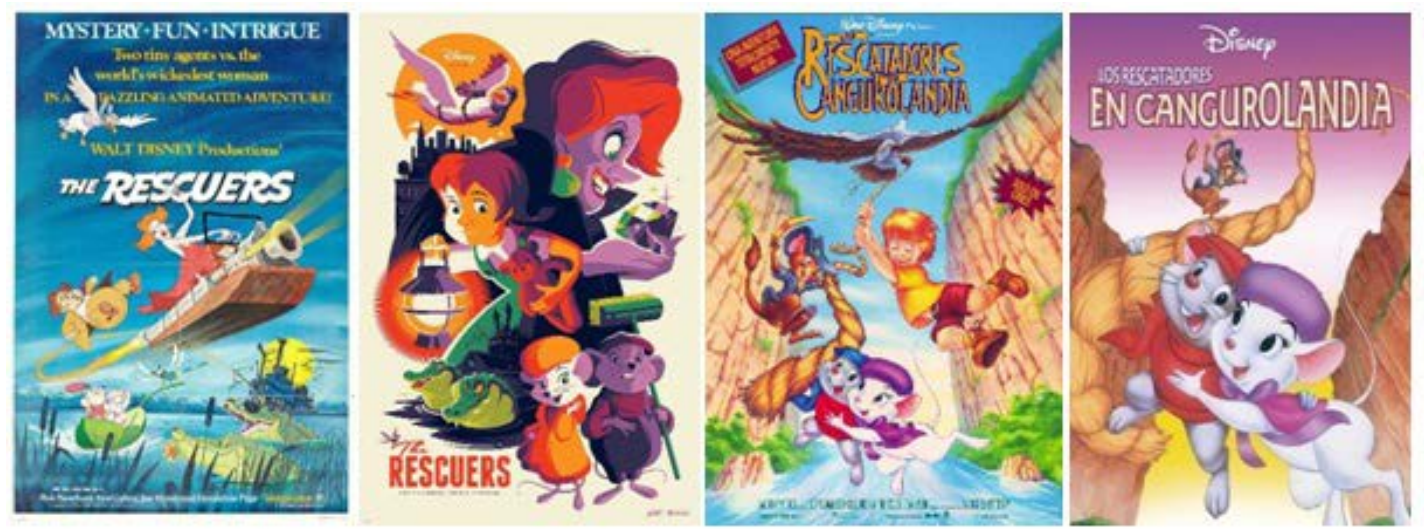

Figura 8: Carteles de Los rescatadores en Cangurolandia (The Rescuers Down Under, Shumacher, 1990) 
INNOVACIÓN TEÓRICA

En Los rescatadores en Cangurolandia la variedad es grande, y los ejemplos muy diversos. La década de 1990 se iniciaba con multitud de cuestiones pendientes (la postmodernidad o la primera guerra del Golfo serían detonantes a tener en cuenta), y las tipografías utilizadas visibilizan esta situación de tránsito e indefinición. En el primer cartel, el original en inglés, encontramos unas letras blancas, de trazo suelto (como los letreros de cartones promocionales de las tiendas). En el trabajo del diseñador Tom Whalen para el proyecto Mondo, se recupera una estética sesentera. Vemos aquí un espléndido trabajo de ilustración, donde dominan los contrastes y el color, ofreciendo un producto muy pensado para público mayoritario, de distribución online.
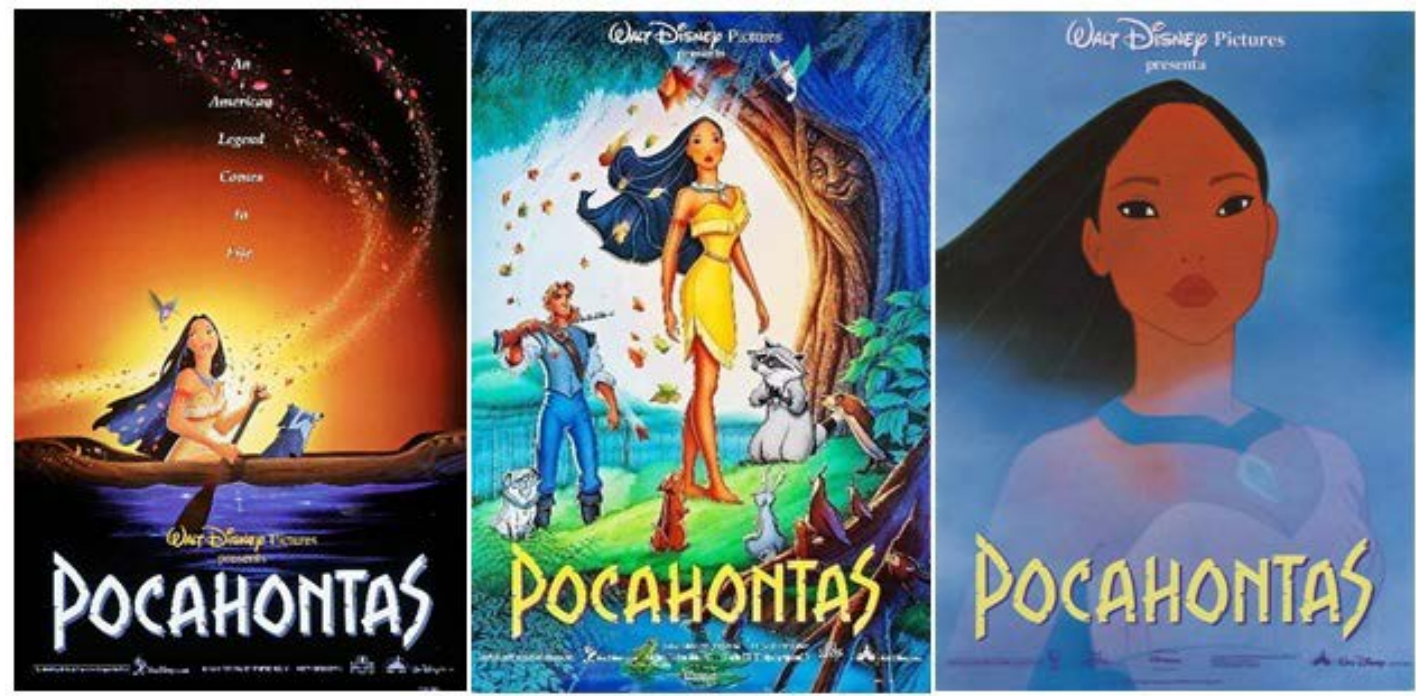

Figura 9: Carteles de Pocahontas (Pocahontas, Pentecost, 1995)

Las letras de la película Pocahontas han quedado marcadas en nuestra memoria (Alegría, Acevedo y Rojas, 2018), al igual que ocurre con Mulan o Frozen. No es casualidad que estas letras consigan su cometido. Cuando el título del film se reduce a una sola palabra, y además es el nombre de la protagonista, resulta muy fácil encajar dicho mensaje visual. En estos tres casos coincide, además, que son heroínas, mujeres que llevan a cabo hazañas memorables. Se trata de una palabra en mayúsculas, cuyo argumento compositivo viene marcado por la referencia a un tipo de escrituras vinculadas al mundo de la naturaleza, a la navaja que inscribe 
sobre la madera del tronco las letras de un nombre. En los ejemplos que presentamos coincide la posición del título en la parte inferior del cartel, ocupando todo el espacio de la base del papel. A pesar de ser 10 letras, se trata de cuatro silabas, muy sonoras. La cacofonía doble " 0 " más doble " $A$ " también ayuda a rememorarlas con facilidad. La $\mathrm{H}$ central equilibra el conjunto.

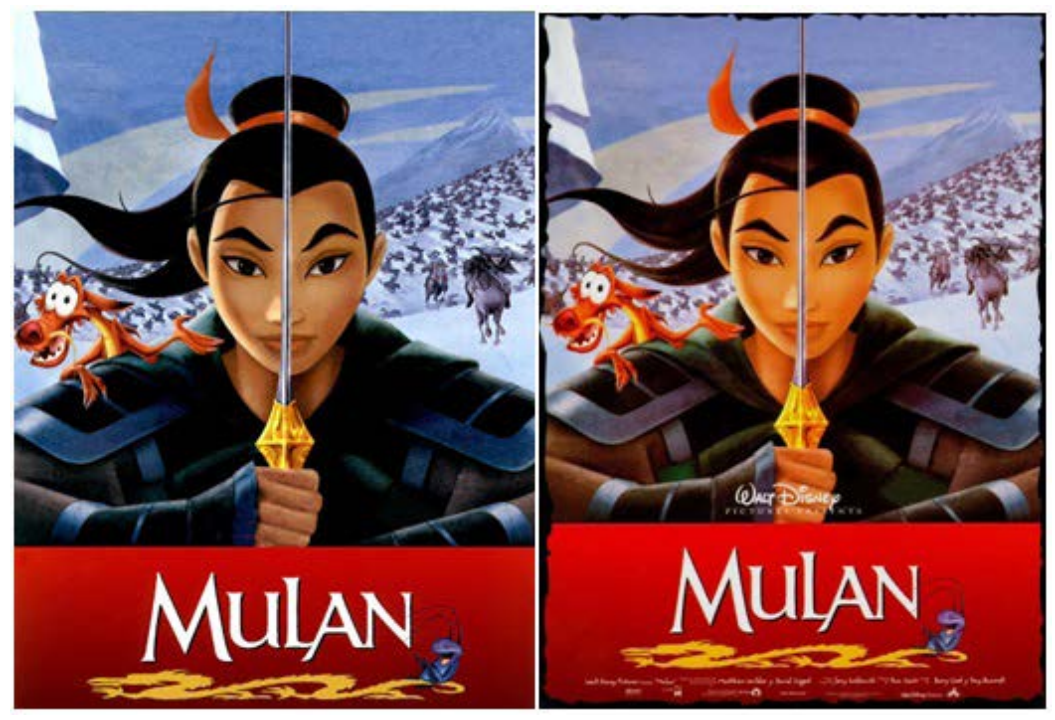

Figura 10: Carteles de Mulan (Mulan, Coats, 1998)

De nuevo en el caso de Mulan observamos un evidente paralelismo entre las versiones en inglés y español. El título se mantiene intacto, al igual que la tipografía utilizada (fuente Mulan), un híbrido que maneja rasgos caligráficos uniendo estratégicamente mayúsculas y minúsculas. Se trata de un logro por parte de la productora, que consigue de este modo unificar a nivel global la imagen del producto. Las cinco letras elaboran un discurso con los remates y las uniones para acercarse a las humanísticas del renacimiento, pero al mismo tiempo dejar rastro de los orígenes orientales del mito, algo que resaltan la " $u$ " aparentemente minúscula, pero del tamaño del resto, el pie izquierdo alargado de la A y la L que se une a dicha letra. El esfuerzo por los equilibrios queda patente también en la composición del cartel, donde el filo de una espada en alto divide por la mitad toda la imagen. Una solución muy oriental y convincente. 

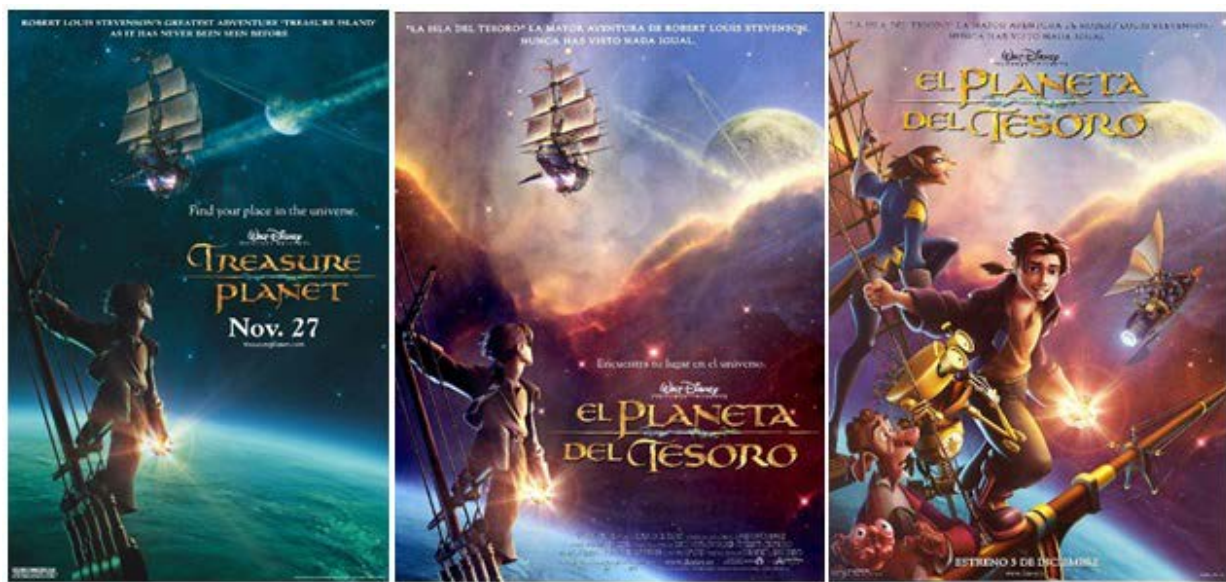

Figura 11: Carteles de El planeta del tesoro (Treasure Planet, Clements, Conli y Musker, 2002)

Recuperando un título clásico de Robert Stevenson, pero en versión espacial, El planeta del tesoro nos presenta un cartel que mezcla elementos de aventuras de piratas y viajes siderales. Sin embargo, las letras se diseñan con un clarísimo acento de caligrafía uncial, más cercana a la escritura manual carolingia medieval que al mundo imaginario del futuro. Lo cierto es que la versión en español respeta estratégicamente la tipografía original. A destacar el elemento central, una línea horizontal con fileteado que también está en ambas versiones.
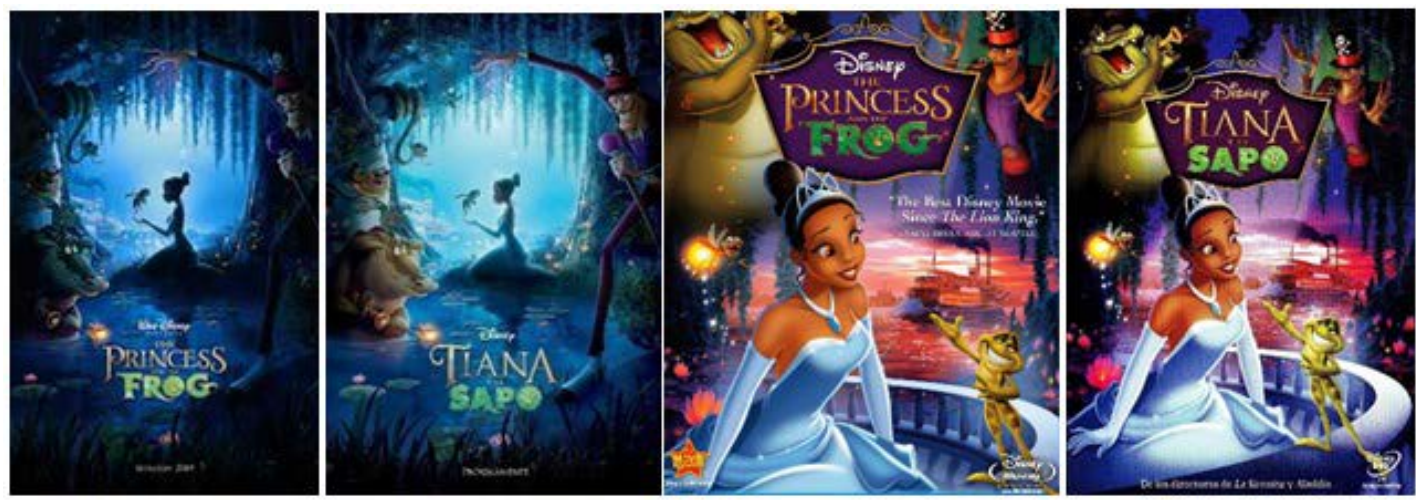

Figura 12: Carteles de Tiana y el sapo (The Princess and the Frog, del Vecho y Lasseter, 2009) 
En el caso de Tiana y el sapo de nuevo se unifican los criterios estilísticos a nivel global, pero en esta ocasión la traducción del título no es literal, ya que se ha cambiado "the princess" por el nombre "Tiana". La "o" de la palabra sapo se equipara a la de "frog", y en ambos idiomas se mantiene el color verde de las mayúsculas utilizadas. Lo que sí detectamos es un escrupuloso respeto por la imagen, que en los carteles de los dos idiomas es idéntica.
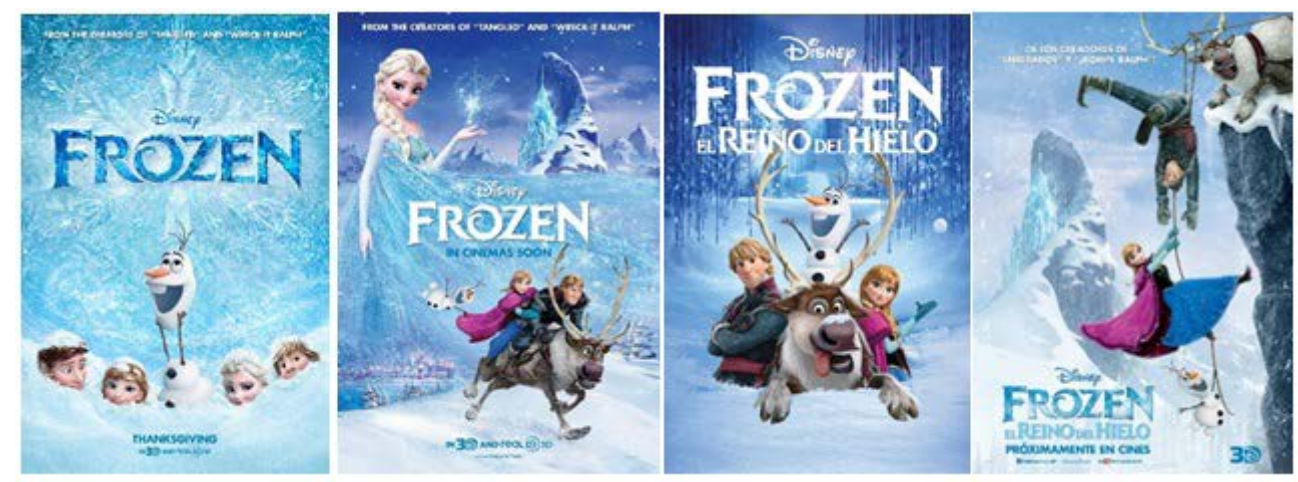

Figura 13: Carteles de Frozen: el reino del hielo (Frozen, del Vecho y Lasseter, 2013)

El último de los títulos seleccionados es un gran éxito de la productora, que ha conseguido de nuevo instalar en nuestro imaginario una canción y unas letras que no pasan desapercibidas, ni se olvidan fácilmente. De nuevo un musical, y una heroína joven; la primera con condición de reina. No podemos entender la obsesión del doblaje y de los cambios de título en español, introduciendo un subtítulo bastante innecesario ("el reino de hielo"). Pero las mayúsculas del nombre se mantienen y el diseño de creación también. La letra " 0 " es, en muchos de los títulos de Disney, elemento creativo por excelencia.

\section{Títulos principales y de crédito en las películas Disney}

Del mismo modo que el cartel acaba convirtiéndose en un reflejo válido para cada una de las producciones Disney, la esmerada elaboración de los títulos de crédito merece una atención especial (Gamonal, 2011). Durante las primeras cuatro décadas en las que se comercializan los productos Disney se manifiesta la ausencia de títulos fina- 
les (end titles), de manera que toda la información aparece previamente. Además, resulta significativo rescatar que la información compartida se reduce a: producción, dirección, personajes, animación y melodías; obviando así al resto de profesionales. De hecho, en los primeros cuatro largometrajes analizados se mantiene el anonimato de quienes diseñan los títulos principales y de crédito correspondientes. Como característica común a Fantasía, Música, maestro, La bella durmiente y Los Aristogatos, destaca la sucesión de títulos principales de la película acompañados por la reproducción musical de temas clave en las mismas. En Fantasía y Música, maestro se recurre también a elementos musicales como las siluetas de profesionales orquestales en la primera y de teclas del piano en la segunda. En La bella durmiente se utilizan motivos y ornamentos medievales para acompañar las letras. Con Los Aristogatos se introducen por primera vez en los main titles figuras del propio largometraje, en este caso los personajes gatunos que protagonizan la historia. De hecho, para presentar el título de la película primero se hace en lengua inglesa Aristocats y tras una secuencia en la que Berlioz, uno de los mininos, estira la palabra; la letra " $c$ " cambia por una " $\mathrm{g}$ " y se incluye la "o" de la versión española, resultando así Aristogatos. Esto contribuye a introducir a la audiencia en la trama y el tema central de la misma desde los inicios del film. Se destaca en los últimos dos ejemplos la presencia de la palabra "Technicolor", bajo el título del film, para destacar el proceso tecnológico de animación en color.

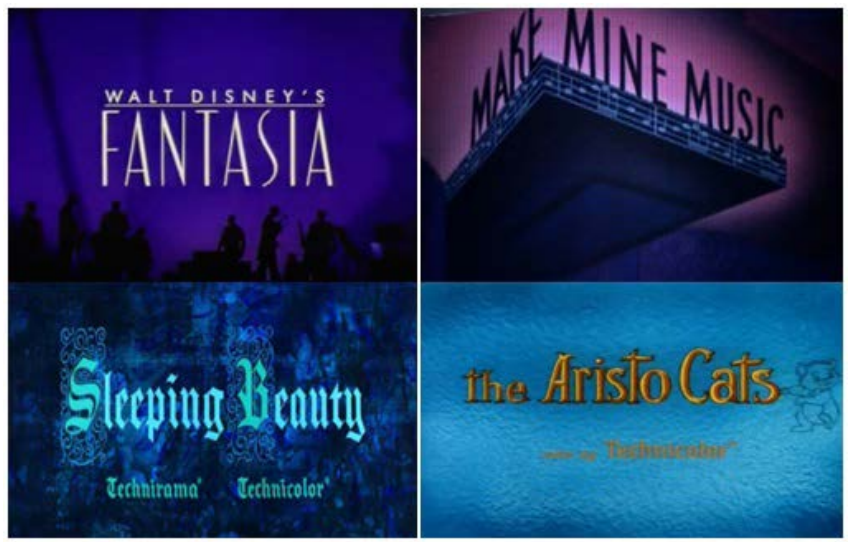

Figura 14: Main titles de Fantasía (Fantasia, Disney, 1940), Música, maestro! (Make mine music, Disney, 1946), La bella durmiente (Sleepy Beauty, Disney, 1959) y Los Aristogatos (Aristocats, Hibler y Reitherman, 1970) 
A partir de la década de 1980 se amplía la información respecto a profesionales con implicación en el proceso de producción de los largometrajes. Así se manifiesta la participación de David Jonas en Design Titles de La bruja novata y de Taron y el caldero mágico, en esta última junto a Ed Garbet. Estos dos ejemplos destacan por el uso de elementos relacionados con la Edad Media. La bruja novata, así como Taron y el caldero mágico, se ambientan igualmente en la Edad Media. En la primera película comentada, toda la información se presenta nuevamente en los main titles, cerrando el filme tras la última escena. No obstante, a partir de Taron y el caldero mágico se presenta el título del filme en los main titles y toda la información referente a profesionales y empresas que participan en la producción de las historias animadas pasan a los end titles. Este planteamiento se utiliza en el resto de filmes.
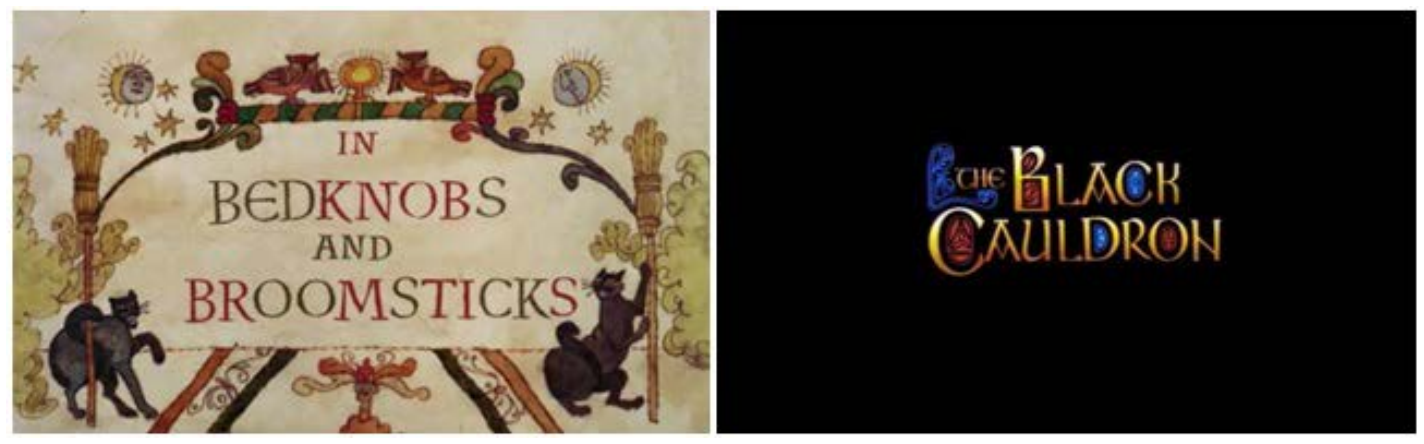

Figura 15: Main titles de La bruja novata (Bedknobs and broomsticks, Walsh, 1971) y Taron y el caldero mágico (The black cauldron, Hale, 1985)

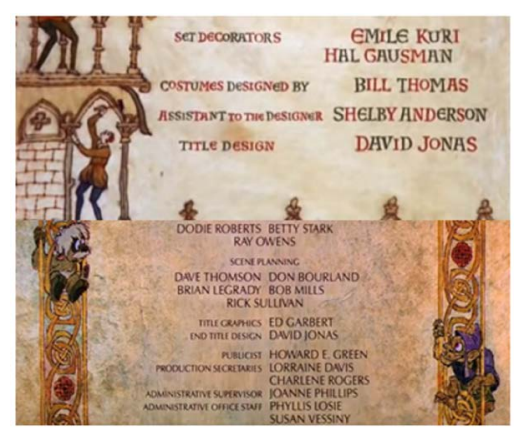

Figura 16: End titles de La bruja novata (Bedknobs and broomsticks, Walsh, 1971) y Taron y el caldero mágico (The black cauldron, Hale, 1985) 
Los ejemplos restantes mantienen el mismo patrón, es decir, en los main titles se presenta únicamente el título del largometraje, mientras que cuando este concluye se procede a la sucesión de los end titles con toda la información referente a la producción del filme, documentación entre la que se incluye la autoría del concepto Design Titles. No obstante, en dichos ejemplos fílmicos se aprecian ligeras diferencias que resultan significativas para el análisis. Mientras que en la mayoría, el título de la película se presenta desde sus inicios, en Pocahontas y Tiana y el sapo se difunde tras el desarrollo de una escena introductoria de varios minutos. Esta situación despierta el interés, sobre todo porque únicamente se da en los largometrajes donde aparecen poblaciones de la alteridad cultural, como afroamericanos y población oriunda. Todos estos títulos coinciden con los presentados en los carteles y carátulas de películas analizadas previamente, a excepción de Los rescatadores en Cangurolandia. Los colores en Pocahontas también presentan una tonalidad más oscura y dual.
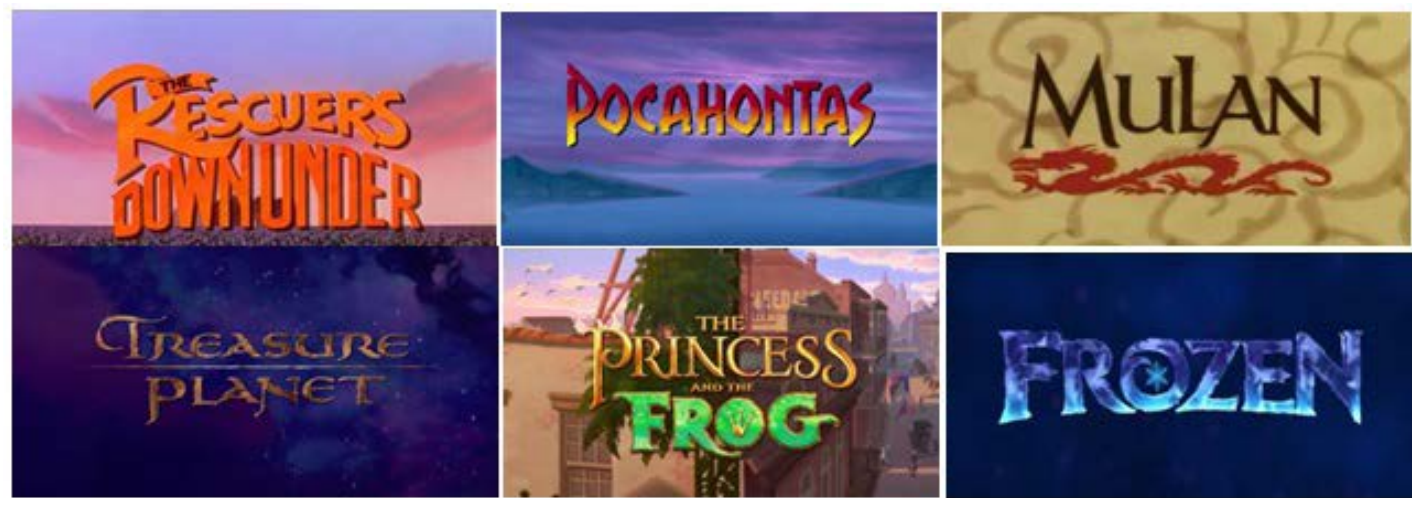

Figura 17: Main Titles de Los rescatadores en Cangurlandia (The rescuers down under, Schumacher, 1990), Pocahontas (Pocahontas, Pentecost, 1995), Mulan (Mulan, Coats, 1998), El planeta del tesoro (The treasure planet, Clements, Conli y Musker, 2002), Tiana y el sapo (The princess and the frog, del Vecho y Lasseter, 2009) y Frozen: el reino de hielo (Frozen, del Vecho y Lasseter, 2013)

En estas últimas seis películas los títulos de crédito se presentan de manera uniforme, mediante una sucesión de letras blancas sobre fondo negro, con toda la 
información relativa a la producción del filme. Carecen de otras imágenes que acompañen la melodía que se reproduce y los listados que se presentan en Los rescatadores en Cangurolandia. Sin embargo, en el resto de ejemplos se introducen dibujos característicos de cada historia. En Pocahontas dicha información se acompaña por lanzas, en Mulan caligrafías chinas, en El planeta del tesoro se introduce la gama amarilla para resaltar cabeceras, en Tiana y el sapo domina el color verde relacionado con dichos anfibios, y en Frozen: el reino de hielo se añaden escudos similares a los que aparecen en el castillo de Elsa y Anna. Estos elementos contribuyen a una estética Disney y ayudan a asentar en el subconsciente de la audiencia un imaginario característico de la productora.

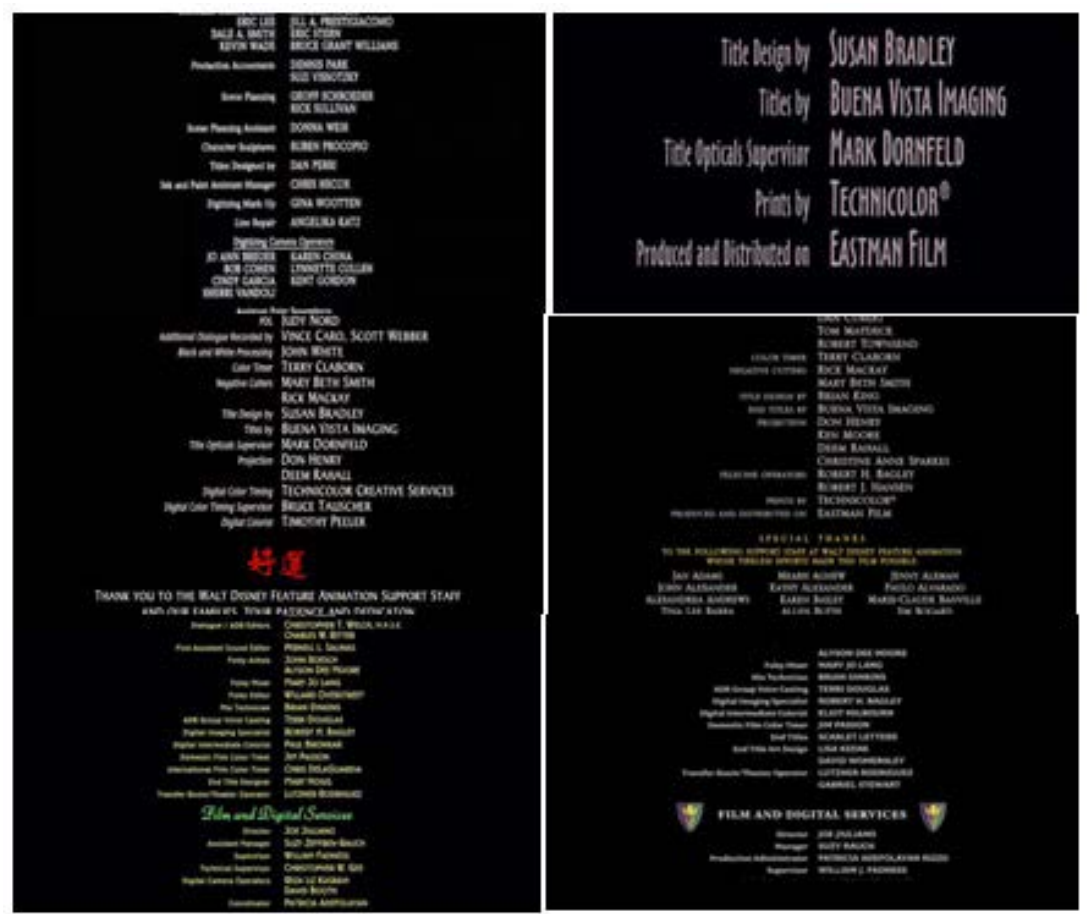

Figura 18: End titles de Los rescatadores en Cangurlandia (The rescuers down under, Schumacher, 1990), Pocahontas (Pocahontas, Pentecost, 1995), Mulan (Mulan, Coats, 1998), El planeta del tesoro (The treasure planet, Clements, Conli y Musker, 2002), Tiana y el sapo (The princess and the frog, del Vecho y Lasseter, 2009) y Frozen: el reino de hielo (Frozen, del Vecho y Lasseter, 2013) 
INNOVACIÓN TEÓRICA

Con todo, se destaca que a lo largo de estas décadas figuran tanto personas particulares como empresas encargadas del Design Titles. Se rescatan las autorías en los siguientes largometrajes: Dan Perri en Los rescatadores en Cangurolandia; Susan Bradley en Pocahontas y Mulan; Brian King en El planeta del Tesoro y Mary Hoggen Tiana y el sapo. Por otro lado, en empresas destaca Buena Vista Imaging como participante en Mulan y El planeta del tesoro; así como Scarlett Letters en Frozen: el reino de hielo. Esta sucesión de participantes diversos en el proceso de diseño de los títulos principales y de crédito de las películas llama la atención, respecto a la uniformidad que guarda la presentación de todos estos en esta última época Disney analizada.

\section{La preocupación por el diseño: de Disney a Almodóvar}

Los carteles (al igual que el tráiler) difunden cada película incluso mucho antes de su estreno. Por tanto, el cartel ya representa al film desde que se inicia la promoción del mismo. Es lo que primero recordamos, junto con las letras del título (Gamonal, 2005). Los grandes directores de cine siempre han elegido buenos diseñadores para generar esta gráfica tan privilegiada, aunque poco valorada profesionalmente: "A pesar de que vivimos en una cultura con fuerte predominio de lo visual, o precisamente por eso, el gran público no se interesa por los carteles de cine. Los consume sin reparar en ellos ni preguntarse por sus creadores, como se consume en general el diseño, que forma parte de la iconosfera y configura nuestra cultura de la imagen" (Pedraza, 1991, p. 86).

La prueba de la importancia que adquieren estos diseños bien elaborados (Sennett, 2013) es que nos trasladan a las escenas de cada película, como ocurre con la cartelería y tipografías en los films de Alfred Hitchcock, Stanley Kubrick, Steven Spielberg, Woody Allen, Agnès Varda, Céline Sciamma, Icíar Bollaín o Quentin Tarantino. Elegir un buen diseño tipográfico y de cartel para un film es una labor de equipo que requiere numerosas decisiones por parte de cada especialista. Disney siempre ha recurrido a grandes profesionales, que permanecieron en el anonimato, hasta que en las últimas décadas ya constan figuras como David Jonas, Dan Perri, 
Susan Bradley, Brian King, Mary Hogg o la productora Scarlet Letters. Un director tan renombrado como Pedro Almodóvar siempre ha sabido elegir a buenos diseñadores para sus carteles, y si en las últimas producciones ha contado con creadores como Oscar Mariné, Xavier Mariscal o Juan Gatti (en otros momentos también fueron Carlos Berlanga y Ceesepe), no podemos perder de vista su colaboración con Iván Zulueta en las primeras películas que hizo. Esta cartelería puede servirnos para educar en diversidad (Alfeo Álvarez, González de Garay y Rosado Millán, 2011). Zulueta era, además, director de cine, y por tanto buen conocedor de los intestinos de esta industria cultural. Le daba mucha importancia al rótulo, con una maestría técnica elogiable, utilizando a veces el choque del estilo de las letras y del contenido figurativo del cartel, incorporando referencias al cómic, a los tebeos antiguos y a los álbumes de cromos (Pedraza, 1991). Sus carteles para Almodóvar se han convertido en referencia ineludible (Laberinto de pasiones, Entre tinieblas, ¿Qué he hecho yo para merecer esto?). Esto nos da a entender hasta qué punto los universos Disney o Almodóvar tienden puentes gráficos e icónicos en su correspondiente cartelería, ya que el mundo del cineasta español "terrible pero no tanto, melodramático de comedia, de plástico y de pasión" (...) "tan rico visualmente, tan graciosamente monstruoso, tan terriblemente, frívolamente chillón" (Pedraza, 1991, p. 90), puede que esté más cerca del engranaje Disney que de otras referencias a quienes suelen emparentarlo (Buñuel, Fellini, Fassbinder).

\section{Conclusiones}

El imaginario Disney se construye combinando todos los elementos visuales y auditivos de cada film, entendiendo como conjunto de la obra también los aspectos tangenciales como la cartelería con la que se publicita y las carátulas con las que se comercializa, así como el diseño de letras y títulos de crédito de las películas. Las letras de los títulos de crédito experimentan una evolución a lo largo de la colección que se ajustan al momento histórico de cada producción, algo que se perpetúa en las consecutivas reposiciones. Desde la inicial brevedad de los mismos, se evoluciona hasta lograr una especificación de todas las personas que participan en el desarrollo del largometraje y sus paralenguajes. Los diseños no son arbitrarios, ya que se encuentran relacionados con la temática de cada película. 


\section{INNOVACIÓN TEÓRICA}

Tal y como nos habíamos propuesto en los objetivos de la investigación, hemos revisado desde la cultura visual los aspectos formales y de contenido que identifican el imaginario Disney, analizando las letras en los diseños de carteles y títulos de crédito, confirmando su capacidad de adaptación, algo que incide en la creación de una mitología visual muy poderosa. Al sondear las posibilidades educativas del estudio, comprobamos la necesidad de incorporar estas cuestiones en la formación del profesorado, convirtiendo estos elementos en material válido para educar en sensibilidad. Siendo los medios un poderoso escaparate cultural, las letras se convierten en imágenes valiosas, de modo que conviene indagar en sus valores gráficos y educativos, más allá de su presencia como elemento verbal.

Numerosos autores han estudiado la producción Disney desde distintas perspectivas, pero son pocos los trabajos de investigación que inciden en el uso de las letras desde la perspectiva de la cultura visual. Justin Callaghan ha llegado a diseñar la fuente Waltograph, ambientada en el logo de Walt Disney, y artistas de todas las épocas han interpretado sus creaciones estéticas. Nosotros hemos optado por elaborar un análisis diacrónico del desarrollo de las letras de las producciones Disney en base a las letras del título, el cartel, los main titles y los end titles. De este modo auspiciamos un mayor acercamiento a la importancia que tienen las letras en el imaginario de uno de los conglomerados de comunicación más grandes del mundo. Al revelar sus características y su función en cada momento histórico, las letras de Disney nos sirven para conocer mejor los mecanismos de sus producciones, implementando así nuevas posibilidades de estudio que permitirán mejorar cuestiones candentes en clave creativa, tecnológica, comunicacional y educativa. Si las letras Disney difunden un modelo patriarcal hegemónico, al igual que ocurre con sus películas, su conocimiento nos permitirá elaborar un discurso crítico que sea consecuente con el conocimiento de dicha realidad.

\section{Referencias}

Aguirre, I. (2005). Teorías y prácticas en educación artística. Ideas para una revisión pragmatista de la experiencia estética. Barcelona: 0ctaedro.

Alegría L., Acevedo P. y Rojas C (2018). Patrimonio cultural y memoria. El giro social de la memoria. Revista Austral de Ciencias Sociales, (34) 21-35. doi: https://doi.org/10.4206/rev.austral.cienc.soc.2018.n34-03 
Albaladejo Ortega, S., \& Sánchez Martínez, J. (2019). El ecosistema mediático de la ficción contemporánea. ICON014 Revista Científica de Comunicación y Tecnologías Emergentes, 17(1), 15-38. doi: https://doi.org/10.7195/ri14. v17i1.1241

Alfeo Álvarez, J. C., González de Garay, B., \& Rosado Millán, M. J. (2011). Adolescencia e identidades LGBT en el cine español. Evolución, personajes y significados. ICONO 14 Revista Científica de Comunicación y Tecnologías Emergentes, 9(3), 5-57. doi: https://doi.org/10.7195/ri14.v9i3.131

Alonso-Sanz, A. (2013). A favor de la Investigación Plural en Educación Artística. Integrando diferentes enfoques metodológicos. Arte, Individuo y Sociedad, 25(1), 111-120.

Barber, M. (2015). Disney's Female Gender Roles: The Change of Modern Culture [Tesis Doctoral]. Indiana: Indiana State University.

Barthes, R. (1986). Lo obvio y lo obtuso. Imágenes, gestos, voces. Barcelona: Paidos. Benjamin, W. (2003). La obra de arte en la época de su reproductibilidad técnica. México: Ítaca.

Briggs, A. y Burke, P. (2002) De Gutenberg a Internet. Una historia social de los medios de comunicación. Madrid: Taurus.

Cantillo, C. (2011). Análisis de la representación femenina en los medios. El caso de las princesas Disney. Making of: Cuadernos de cine y educación, 78, 51-61.

Cantillo, C. (2015). Del cuento al cine de animación: semiología de una narrativa digital. Revista de Comunicación de la SEECI, 38, 133-145. doi: https://doi. org/10.15198/seeci.2015.38.115-140

Castro-Martinez, A. y Diaz-Morilla, P. (2019). El proceso de enseñanza-aprendizaje de la Historia del Cine a través de una estrategia de storytelling y storydoing teatral aplicada al ámbito universitario. ICONO 14 Revista Científica de Comunicación y Tecnologías Emergentes, 17(2), 154-181. doi: https://doi. org/10.7195/ri14.v17i2.1378

Debord, G. (1967). La société du spectacle. Paris: Buchet-Chaste.

Dewey, J. (2008). El arte como experiencia. Barcelona: Paidós.

Duncum, P. (2015). Transforming Art Education into Visual Culture Education Through Rhizomatic Structures. Anadolu Journal of Educational Sciences International, 5(3), 47-64. doi: https://doi.org/10.18039/ajesi.66849 
Even-Zohar, I. (1990). Polisystem Theory. Poetics Today, 11 (1), 9-26

Foucault, M. (1998). Las palabras y las cosas. Una arqueología de las ciencias humanas. México: Siglo XXI.

Freire, P. (2015). Pedagogia da autonomia: saberes necessários à prática educativa. Rio de Janeiro: Paz e Terra.

Freitas, R., Coutinho, S. y Waetcher, H. (2013). Análise de Metodologias em Design: a informação tratada por diferentes olhares. Estudosem Design, 21(1), 1-15.

Frutiger, A. (2007). Reflexiones sobre signos y caracteres. Barcelona: Gustavo Gili.

Gamonal Arroyo, R. (2005). Títulos de crédito. Píldoras creativas del diseño gráfico en el cine. Revista ICONO 14 Revista Científica de Comunicación y Tecnologías Emergentes, 3(2), 43-67. doi: https://doi.org/10.7195/ri14.v3i2.418

Gamonal Arroyo, R. (2011). Retórica aplicada a la Enseñanza del Diseño Gráfico. Operaciones para la creatividad. Revista ICONO 14 Revista Científica de Comunicación y Tecnologías Emergentes, 9(3), 426-438. doi: https://doi.org/10.7195/ri14.v9i3.128 Giroux, H. A. (2001). El ratoncito feroz: Disney o el fin de la inocencia. Madrid: Fundación Germán Sánchez Ruipérez.

Groupe $\mu$ (1992). Traité du signe visuel: Pour une rhétorique de l'image. Paris: Seuil. Hernández, F. (2008). La investigación basada en las artes. Propuestas para repensar la investigación en educación. Educatio Siglo XXI, 26, 85-118.

Hernández, F. (2010). Educación y cultura visual. Barcelona: Octaedro.

Irwin, R.; 0'Donoghue, D. (2012). Encountering pedagogy through relational art practices. International Journal of Art \& Design Education, 31(3), 221-236. doi: https://doi.org/10.4324/9781315467016-11

Lobovikov-Katz, A. (2019). Methodology for Spatial-Visual Literacy (MSVL) in Heritage Education: Application to Teacher Training and Interdisciplinary Perspectives. Revista Electrónica Interuniversitaria de Formación del Profesorado, 22(1). doi: https://doi.org/10.6018/reifop.22.1.358671

Mirzoeff, N. (2006). On Visuality. Journal of Visual Culture, 5(1), 53-79.

Munari, B. (2019). Artista y diseñador. Barcelona: Gustavo Gili.

McLuhan, M. (1994). Understanding Media: The Extensions of Man. Cambridge, MA: MIT Press.

Nake, F. y Grabowski, S. (2017). Think the Image, Don't make it! On Algorithmic Thinking, Art Education and Re-Coding. CITAR Journal of Science and Technology of the Arts, 9(3), 21-31. doi: https://dx.doi.org/10.7559/citarj.v9i3.458 
Pacheco, R., Moura, A., Soares, A. I., \& Almeida, C. (2019). DocNomads, Ao-Norte y ESE: un proyecto de alfabetización cinematográfica implementado en Viana do Castelo. Revista ICONO 14, 17(2), 182-204. doi: https://doi.org/10.7195/ ri14.v17i2.1354

Pedraza, P. (1991). Iván Zulueta: unos carteles de cine. Fragmentos. Revista de arte, 17. $85-92$

Postman, N. (2001).Divertirse hasta morir. El discurso público en la era del "show business". Barcelona: La tempestad.

Ramon, R. (2012). Lladró: análisis de la creación cultural de una estética. De la tradición industrial de la cerámica valenciana a la recepción social de una marca. Tesis doctoral. València: Universitat de València.

Ramon, R. (2017). Pedagogías visuales y artísticas en torno al objeto cotidiano. Artseduca, 18, 30-53.

Rolling, J. H. (2017). Arts-Based Research in Education. EnLeavy, P. (ed.) Handbook of Arts-Based Research. New York: Guilford, 493-510.

Said-Valbuena, W. (2019). Prefigurar, co-crear, entretejer. Diseño, creatividad, interculturalidad. Arte, Individuo y Sociedad 31(1), 111-129.doi: https://doi. org/10.5209/ARIS.59369

Sancho-Gil, J. M.; Hernández, F. (2018). La profesión docente en la era del exceso de información y la falta de sentido. RED. Revista de Educación a Distancia, 56, artic. 4, 31-01-2018. doi:https://doi.org/10.6018/red/56/4

Sennett, R. (2013). El artesano. Barcelona: Anagrama.

Stake, R. E. (2005). Investigación con estudio de casos. Madrid: Morata.

Vaquerizo Domínguez, E. (2020). Medios de comunicación y flujos culturales internacionales: la vigencia actual del informe McBride. Revista de Comunicación de la SEECI,51, 43-62. doi: https://orcid.org/0000-0002-4146-9900

\section{(2) (1)}

Este obra está bajo una licencia de Creative Commons Reconocimiento 4.0 Internacional. 